\title{
ANALISIS USAHATANI BROKOLI (Brassica oleracea L) DAN PEMASARANNYA DI DESA SUMBER URIP KECAMATAN SELUPU REJANG KABUPATEN REJANG LEBONG
}

\section{On-Farm and Marketing Analysis of Broccoli in Sumber Urip Selupu Rejang Subdistrict District of Rejang Lebong}

\author{
Bembi Akbar Serawai, Sriyoto, dan Ellys Yuliarti \\ Jurusan Sosial Ekonomi Pertanian Fakultas Pertanian Universitas Bengkulu \\ bembiakbars@yahoo.com
}

\begin{abstract}
This research was conducted with the purpose to: (1) Determine the system of financing farming Broccoli, (2) Calculate farm income of Broccoli, (3) Investigate marketing channels of Broccoli, Calculate its marketing margin and knowing marketing efficiency Broccoli in Sumber Urip village Sub-District Selupu Rejang District of Rejang Lebong. Respondents of Broccoli Farmers are censused 45 Farmers while marketing agencies are determined with Snowball Sampling, total respondent marketing agencies are 25 respondents. The result of this research indicated that the average farmers in the Sumber Urip village their own capital resources obtained from previous farming Broccoli. The averaged income of Broccoli as Rp 5.850.717/Ut/MT. The marketing analysis indicated that the only Broccoli marketing channel in Sumber Urip village was through Farmers $\rightarrow$ Countryside $\rightarrow$ Wholeseller $\rightarrow$ Town Wholeseller $\rightarrow$ Retailers $\rightarrow$ Final Consumers. The marketing margin analysis showed that the total marketing margin Broccoli is $\mathrm{Rp} 10.942 / \mathrm{Kg}$. Broccoli Marketing efficiency analysis results in Sumber Urip shows that every marketing agencies Broccoli studied all efficient it can be seen from the value criteria Countryside Wholeseller is 1.28, Districts Traders 5.52, Town Wholeseller is 1,83 and Retailers 19,21 .
\end{abstract}

Keywords: broccoli, income, marketing channels, margin, efficiency

\section{PENDAHULUAN}

Indonesia merupakan daerah agraris dimana sebagian besar penduduknya bekerja pada sektor pertanian. Sektor pertanian menjadi salah satu sektor yang berperan penting bagi perekonomian di Indonesia. Umumnya pertanian terdiri dari enam bagian yaitu, tanaman pangan, tanaman perkebunan, hortikultura, perikanan, kehutanan, dan peternakan.

Komoditi hortikultura terdiri dari buah-buahan, sayur-sayuran, tanaman hias dan obat-obatan. Pemilihan komoditi sayuran dan buah-buahan untuk diusahakan merupakan salah satu upaya untuk mempercepat pengembangan 
perekonomian pedesaan pada khususnya dan negara pada umumnya (Soekartawi, 1995).

Propinsi Bengkulu merupakan Propinsi dimana sektor pertanian menjadi salah satu sektor utama dalam peningkatan Pendapatan Asli Daerah (PAD). Terdapat ragam pertanian yang diusahakan oleh masyarakat Bengkulu salah satunya adalah sektor sayur-sayuran. Daerah yang menjadi basis tanaman sayur-sayuran pada Propinsi Bengkulu yaitu Kabupaten Rejang Lebong. Kabupaten Rejang Lebong merupakan daerah utama penghasil sayuran di Propinsi Bengkulu. Data BPS Kabupaten Kota di Propinsi Bengkulu 2013 menujukan bahwa luas panen tanaman sayuran di kabupaten Rejang Lebong yaitu 17.197 Ha.

Salah satu Desa yang menjadi sentra sayuran di Kabupaten Rejang Lebong adalah Desa Sumber Urip. Diantara macam-macam jenis sayuran yang diusahakan petani di Desa Sumber Urip, Brokoli salah satu sayuran yang masih jarang diusahakan oleh petani hal ini terkait pembiayaan usahatani. Secara umum petani Brokoli untuk memperoleh sumber pembiayaannya memanfaatkan keberadaan pada sumber pembiayaan formal dan non formal dengan berbagai konsekuensinya. Walaupun didalam mengakses sumber pembiayaan formal yang masih rendah, karena berbagai bentuk sistem aturan dan persayaratan yang dianggap masih sulit yang selama ini menjadikan polemik tersendiri untuk memperoleh sumber modal yang murah dan mudah.

Permintaan akan Brokoli yang rendah di tingkat konsumen dan harga jual yang cukup tinggi membuat tanaman ini kurang menjadi pilihan utama masyarakat, hanya konsumen tertentu saja yang mengkonsumsi Brokoli sebagai menu sayuran pada makanan keseharian.

Terlepas dari itu, maka pemasaran menjadi hal yang sangat penting, jika mekanisme pemasaran berjalan baik, maka semua pihak yang terlibat akan diuntungkan. Oleh karena itu peran lembaga pemasaran yang biasanya terdiri dari produsen, tengkulak, pedagang pengumpul, broker, eksportir, importir dan yang lainnya menjadi amat sangat penting. Biasanya pada negara berkembang, lembaga pemasaran untuk pemasaran hasil pertanian masih lemah (Soekartawi, 2003).

Dari uraian latar belakang diatas, maka terdapat empat tujuan dari penelitian ini. Pertama, untuk mengetahui sistem pembiayaan usahatani Brokoli di Desa Sumber Urip. Tujuan Kedua menghitung pendapatan usahatani Brokoli di Desa Sumber Urip, ketiga mengetahui saluran pemasaran dan menghitung Distribusi Pemasaran Brokoli di Desa Sumber Urip dan tujuan keempat yaitu menghitung marjin dan mengetahui efisiensi pemasaran Brokoli di Desa Sumber Urip Kecamatan Selupu Rejang. 


\section{METODE PENELITIAN}

\section{Lokasi dan Waktu Penelitian}

Penentuan daerah lokasi penelitian dilakukan secara sengaja (Purposive) di Desa Sumber Urip Kabupaten Rejang Lebong. Hal ini didasarkan dengan pertimbangan bahwa mayoritas penduduk Desa Sumber Urip bekerja sebagai petani sayuran. Penelitian ini dilakukan pada tanggal 5 Februari sampai dengan 5 Maret 2016.

\section{Metode Penentuan Responden}

Pengambilan sampel responden petani dilakukan dengan menggunakan teknik sensus Jumlah populasi petani yang mengusahakan tanaman Brokoli di Desa Sumber Urip sebanyak 45 petani jadi sampel dalam penelitian ini sebanyak 45 petani. Untuk responden saluran pemasaran dilakukan teknik snowball sampling, diperoleh 5 lembaga pemasaran tingkat desa, 13 pedagang pengumpul kecamatan, 3 pedagang pengumpul kota dan 4 pedagang pengecer.

\section{Metode Pengambilan Data}

Data primer yaitu data yang didapat secara langsung kepada responden dengan melakukan wawancara yang dibantu daftar pertanyaan (Kuisioner), data primer dalam penelitian ini adalah data identitas petani, data usahatani Brokoli, dan data pemasaran Brokoli. Data sekunder yaitu data yang didapat dari kepustakaan atau yang telah dipublikasikan dari pihak terkait seperti instansi dan dinas. Data sekunder pada penelitian ini adalah data jumlah petani yang mengusahakan tanaman Brokoli, data luas lahan usahatani Brokoli dari dinas pertanian, dan sebagainya.

\section{Metode Analisis Data}

Untuk mengetahui sistem pembiayaan usahatani Brokoli maka akan dianalisa dengan menggunakan analisa deskriptif. Analisis ini akan menggambarkan sistem pembiayaan usahatani Brokoli pada yang dilakukan petani di Desa Sumber Urip.

Untuk menganalisis pendapatan usahatani Brokoli maka digunakan rumus pendapatan usaha sebagai berikut (Soekartawi, 1995):

$$
\begin{aligned}
& \text { I }=\text { TR }- \text { TC } \\
& \text { TR }=\text { Y x Py } \\
& \text { TC }=\text { VC }+ \text { FC }
\end{aligned}
$$

Keterangan:

$$
\begin{array}{ll}
\mathrm{I} & =\text { Pendapatan/ Income }(\mathrm{Rp} / \mathrm{Ut} / \mathrm{MT}) \\
\mathrm{TR} & =\text { Jumlah Penerimaan }(\mathrm{Rp} / \mathrm{Ut} / \mathrm{MT}) \\
\mathrm{TC} & =\text { Total Pengeluaran Usaha Tani }(\mathrm{Rp} / \mathrm{Ut} / \mathrm{MT}) \\
\mathrm{Q} & =\text { Jumlah Produksi }(\mathrm{Kg} / \mathrm{Ut} / \mathrm{MT}) \\
\mathrm{P} & =\text { Harga }(\mathrm{Rp} / \mathrm{Kg})
\end{array}
$$


ISSN: 1412-8837

VC = Biaya Variabel Usaha Tani $(\mathrm{Rp} / \mathrm{Ut} / \mathrm{MT})$

FC = Biaya Tetap Usaha Tani $(\mathrm{Rp} / \mathrm{Ut} / \mathrm{MT})$

Dalam mengidentifikasi saluran dan distribusi pemasaran Brokoli maka akan digunakan teknik snowball yaitu dengan menelusuri satu persatu pelaku pemasaran Brokoli dari produsen hingga konsumen akhir. Selanjutnya akan dianalisa secara deskriptif bagaimana pola saluran pemasaran dan berapa distribusi pemasaran Brokoli di Desa Sumber Urip.

Untuk menghitung marjin pemasaran Brokoli setiap lembaga pemasaran maka digunakan rumus (Anindita et al (1983) dalam Wijaya et al (2012)).

Mji = Psi - Pbi

Marjin pemasaran juga dapat dihitung dengan menjumlahkan biaya dan keuntungan pemasaran dan dapat ditulis:

$\mathbf{M j i}=$ bti + ni

Dengan menghitung besaran marjin dan biaya pemasaran maka dapat dihitung keuntungan pemasaran dengan menggunakan rumus:

$\mathbf{n i}=\mathbf{M j i}-\mathbf{b t i}$

Sehingga total marjin pemasaran adalah:

$\mathbf{M j}=\sum_{i=1}^{n} M j i$

Dimana:

Mji = Marjin pemasaran pada lembaga pemasaran $\mathrm{ke} \mathrm{i}(\mathrm{Rp} / \mathrm{kg})$

Psi = Harga jual lembaga pemasaran $\mathrm{ke} i(\mathrm{Rp} / \mathrm{kg})$

Pbi = Harga beli lembaga pemasaran $\mathrm{ke} \mathrm{i}(\mathrm{Rp} / \mathrm{kg})$

bti = Biaya pemasaran lembaga pemasaran $\mathrm{ke} \mathrm{i}(\mathrm{Rp} / \mathrm{kg})$

пі = Keuntungan lembaga pemasaran $\mathrm{ke} \mathrm{i}(\mathrm{Rp} / \mathrm{kg})$

$\mathrm{Mj} \quad=$ Total marjin pemasaran $(\mathrm{Rp} / \mathrm{Kg})$

Untuk mengetahui efisiensi pemasaran maka digunakan rumus Rasio keuntungan dan biaya. Rasio keuntungan dan biaya pemasaran mendefinisikan besarnya keuntungan yang diterima atas biaya yang dikeluarkan pada proses pemasaran (Limbong et al, 1987).

\section{Rasio Keuntungan dan Biaya $=\frac{\pi}{C 1}$}

Keterangan :

$$
\begin{array}{ll}
\pi & =\text { Keutungan Lembaga Pemasaran } \\
\mathrm{C} 1 & =\text { Biaya Pemasaran } \\
\text { Kriteria : } & \\
\frac{\boldsymbol{\pi}}{\boldsymbol{C} \mathbf{1}} \text { Rasio } & >1 \text { (Pemasaran Efisien) } \\
\frac{\boldsymbol{\pi}}{\boldsymbol{C} \mathbf{1}} \text { Rasio } & <1 \text { (Pemasaran Tidak Efisien) }
\end{array}
$$


ISSN: $1412-8837$

\section{HASIL DAN PEMBAHASAN}

\section{Karakteristik Responden \\ Petani}

Dari hasil penelitian yang dilakukan karakeristik petani Brokoli di Desa Sumber Urip dapat dilihat pada tabel 1.

\section{Tabel 1. Karakteristik Petani Brokoli}

\begin{tabular}{|c|c|c|c|}
\hline No & Karakteristik Responden & $\begin{array}{c}\text { Jumlah } \\
\text { (Jiwa) }\end{array}$ & $\begin{array}{c}\text { Persentase } \\
(\%)\end{array}$ \\
\hline \multirow[t]{4}{*}{1} & Umur (Tahun) & & \\
\hline & $10-30$ & 4 & 8,89 \\
\hline & $31-50$ & 33 & 73,33 \\
\hline & $>50$ & 8 & 17,78 \\
\hline \multirow[t]{5}{*}{2} & Pendidikan Formal & & \\
\hline & Tidak Sekolah & 2 & 4,44 \\
\hline & Sekolah Dasar (SD) & 35 & 77,78 \\
\hline & Sekolah Menengah Pertama (SMP) & 5 & 11,11 \\
\hline & Sekolah Menengah Atas (SMA) & 3 & 6,67 \\
\hline \multirow[t]{4}{*}{3} & Jumlah Tanggungan Keluarga (Jiwa) & & \\
\hline & $\leq 2$ & 3 & 6,67 \\
\hline & $3-4$ & 36 & 80 \\
\hline & $>4$ & 6 & 13,33 \\
\hline \multirow[t]{4}{*}{4} & Pengalaman Berusahatani Brokoli (Th) & & \\
\hline & $<2$ & 2 & 4,44 \\
\hline & $2-4$ & 36 & 80 \\
\hline & $>5$ & 7 & 15,56 \\
\hline \multirow[t]{4}{*}{5} & Luas Lahan (Ha) & & \\
\hline & $0,04-0,12$ & 17 & 37,78 \\
\hline & $0,13-0,24$ & 26 & 57,78 \\
\hline & $>0,24$ & 2 & 4,44 \\
\hline \multirow[t]{3}{*}{6} & Status Kepemilikan Lahan & & \\
\hline & Milik Sendiri & 34 & 75,55 \\
\hline & Sewa & 11 & 24,55 \\
\hline
\end{tabular}

Sumber: Data Primer Diolah, 2016

Mayoritas umur petani Brokoli di daerah penelitian yaitu pada rentang 31-50 tahun dengan jumlah 33 petani atau 73,33\%, pada rentang umur 20-30 tahun sebanyak 4 petani atau $8,9 \%$ dan yang berusia $>50$ tahun sebanyak 8 petani atau 17,8\%. Mayoritas umur petani Brokoli berada pada usia produktif (kurang dari 50 tahun). Petani yang berada pada umur produktif akan cenderung menghasilkan produktivitas yang lebih tinggi. Menurut Mubyarto (1989) dalam Wijaya (2012) petani pada usia produktif akan memberikan hasil kerja lebih baik dan berpengaruh pada produktifitas usahataninya.

Sebagian besar petani Brokoli memiliki pendidikan pada tingkat Sekolah Dasar (SD) sebesar 77,78\%. Sebanyak 11,11\% memiliki pendidikan pada 
tingkat Sekolah Menengah Pertama (SMP), Pada tingkat Sekolah Menengah Atas sebesar 6,7\% dan yang tidak sekolah sebesar 4,4\%. Menurut Susanti et al (2014) pendidikan yang dimiliki petani akan berpengaruh pada kemampuan petani dalam menyerap informasi dan membantu petani dalam mengambil keputusan yang lebih baik.

Dari hasil penelitian mayoritas petani memiliki tanggungan keluarga sebanyak 3-4 orang sebanyak $80 \%$ petani, yang memiliki tanggungan keluarga $<2$ jiwa sebanyak 6,67\% dan 13,33\% memiliki tanggungan lebih dari 4 jiwa. tanggungan keluarga akan berdampak pada strategi nafkah yang akan dijalani petani dari hasil pendapatan usahatani yang dijalankan.

Hasil penelitian menunjukan bahwa $80 \%$ petani di Desa Sumber urip baru mengusahakan Brokoli 2-4 tahun. Hal ini mengindikasikan bahwa usahatani Brokoli merupakan adopsi yang baru yang diterima petani. Pengalaman berusahatani Brokoli ini akan berdampak pada pengetahuan dan pengalaman bercocok tanam yang baik pada usahatani Brokoli, semakin lama pengalaman usahatani yang dijalankan diharapkan petani memiliki kemampuan lebih diakibatkan oleh temuan-temuan di lapangan.

Luas lahan rata-rata usahatani Brokoli di daerah penelitian yaitu 0,16 Ha. Dalam berusahatani Brokoli mayoritas petani memiliki luas lahan pada rentang 0,13-0,24 Ha sebesar 57,77\% dan 37,77\% memiliki luas lahan $<0,13 \mathrm{Ha}$. Hanya 4,46\% petani yang menggunakan luas lahan $>0,24$ ha dalam berusahatani Brokoli sebesar 4,46\%. Luas lahan akan berpengaruh pada tingkat produksi jika diikuti dengan penggunaan input produksi yang tepat (Wijaya, 2012).

Status kepemilikan lahan petani di Desa Sumber Urip terbagi menjadi 2 yaitu milik sendiri dan sewa. Sebesar 75,55\% petani memiliki status kepemilikan lahan milik sendiri dan $24,45 \%$ berstatus sewa. Sebagian besar petani menyewa pada Kodim Rejang Lebong karena sebagian lahan usahatani di Desa Sumber Urip dimiliki oleh Kodim Rejang Lebong. Dari hasil penelitian besaran biaya sewa lahan yaitu Rp 175.000/Patok (20x20m).

\section{Lembaga Pemasaran}

Lembaga pemasaran pada penelitian terdiri dari Pedagang Pengumpul Desa, Pedagang Pengumpul Kecamatan, Pedagang Pengumpul Kota dan Pedagang Pengecer. Dari hasil penelitian yang dilakukan, maka diperoleh karakterisitik Lembaga Pemasaran Brokoli sebagai berikut.

\section{Pedagang Pengumpul Desa (PPD)}

Hasil penelitian menunjukan bahwa mayoritas umur PPD berada pada rentang umur 30-50 tahun, dari 5 responden PPD, sebanyak 4 orang memiliki $<12$ tahun atau pendidikan SMA, sedangkan 1 orang memiliki pendidikan $>12$ tahun. Dari segi pengalaman berdagang mayoritas memiliki pengalaman berdagang kurang dari 20 tahun, hanya 1 responden PPD yang memiliki pengalaman dagang $>20$ tahun. 


\section{Pedagang Pengumpul Kecamatan (PPK)}

Mayoritas umur PPK berada pada umur $<50$ tahun sebesar $84,61 \%$, dan $15,39 \%$ berumur $>50$ tahun. Dilihat dari pendidikan PPK, sebanyak 3 orang $(23,1 \%)$ telah menempuh pendidikan selama 4-6 tahun atau setara Sekolah Dasar (SD) dan sebanyak 9 orang $(69,22 \%)$ telah menempuh pendidikan selama 7-12 tahun atau setara Sekolah Menengah Pertama (SMP) dan Sekolah Menengah Atas (SMA). Terdapat 1 (7,68\%) orang responden yang yang telah berpendidikan lebih dari 12 tahun atau setara dengan perguruan tinggi. Hasil penelitian menunjukan bahwa sebaran tingkat pengalaman berdagang PPK cukup beragam. Sebesar 38,46\% memiliki pengalaman berdagang kurang dari 5 tahun, 15,39\% memiliki pengalaman berdagang dengan rentang 6-10 tahun, dan 38,46\% memiliki pengalaman dagang selama 11-20 tahun dan terdapat satu orang PPK yang memiliki pengalaman berdagang lebih dari 20 tahun. Pengalaman berdagang Brokoli yang dimiliki oleh setiap pedagang cukup erat kaitannya dengan pola pikir, manajerial dalam melakukan kegiatan usaha dan hubungan baik antar setiap lembaga. Hal ini dapat menunjang pedagang dalam menghadapi peluang dan resiko kegiatan usaha yang dijalankan.

\section{Pedagang Pengumpul Kota (PPKP)}

Dari hasil penelitian, keseluruhan PPKP berada pada rentang umur 4150 tahun. Rentang umur tersebut termasuk dalam umur produktif seseorang dimana tingkat kematangan yang dimiliki sudah sangat baik. Tingkat pendidikan formal yang ditempuh dari 3 responden 2 orang $(66,67 \%)$ menempuh pendidikan pada rentang 9-12 tahun dan 1 orang $(33,33 \%)$ menempuh pendidikan $>12$ tahun atau setara dengan Perguruan Tinggi (PT). Pendidikan yang ditempuh akan berdampak pada pola pikir pedagang dimana biasanya semakin tinggi pendidikan seseorang maka ketepatan bertindak akan semakin baik sehingga akan berpengaruh pada usaha yang akan lebih baik. Dilihat dari pengalaman dagang, sebesar 33,33\% memiliki pengalaman dagang $\leq 10$ tahun, 33,33\% memiliki pengalaman dagang 11-20 tahun dan 33,33\% memiliki pengalaman dagang >20 tahun. Semakin lama pengalaman dagang seseorang maka informasi pasar yang ada akan semakin dikuasai dan berdampak postif terhadap usaha dagang yang dijalankan.

Pedagang Pengecer (PP)

Pedagang pengecer dalam penelitian sebanyak 4 orang. Umur pedagang pengecer mulai dari rentang 40-60 tahun sebanyak 2 orang $(50 \%)$ dan umur $>60$ tahun sebanyak 2 orang (50\%). Pendidikan formal yang ditempuh pedagang pengecer sebagian besar pada rentang 10-12 tahun yaitu sebanyak 3 orang $(75 \%)$ dan 1 orang $(25 \%)$ menempuh pendidikan pada rentang 4-6 tahun. Pengalaman dagang $<10$ tahun yang dimiliki pedagang sebanyak 1 orang, 11-20 tahun sebanyak 2 orang dan 1 orang dengan pengalaman berdagang $>20$ tahun. 


\section{Analisa Pembiayaan Usahatani Brokoli}

Biaya yang dibutuhkan petani untuk usahatani Brokoli meliputi sewa lahan, pembelian saprodi (benih, pupuk, pestisida, peralatan usahatani) dan biaya tenaga kerja mulai dari pengolahan lahan, pemeliharaan sampai dengan panen. Hasil penelitian menunjukan bahwa terdapat tiga jenis sumber pembiayaan petani dalam mengembangkan usahatani Brokoli di Desa Sumber Urip antara lain modal sendiri, kerjasama kepada kios-kios saprodi pertanian dan pinjaman kepada pedagang pengumpul. Hasil penelitian menunjukan 88,89\% petani Brokoli di Desa Sumber menggunakan modal sendiri dalam berusahatani Brokoli. Modal sendiri tersebut diperoleh dari hasil usahatani sebelumnya. Artinya petani telah mengatur pengeluaran rumah tangga dan menyisihkan sebagian pendapatan untuk usahatani selanjutnya.

Jenis pembiayaan selanjutnya yang digunakan petani yaitu kerjasama dengan pihak pemilik kios saprodi. Jumlah petani yang menggunakan sistem pembiayaan kerjasama kepada pihak pemilik kios saprodi sebanyak 6,66\% dari total keseluruhan responden. Sistem pembiayaan dengan melakukan pinjaman tersebut sepenuhnya dibiayai oleh pemilik kios saprodi. Selanjutnya jumlah pinjaman tersebut akan dikembalikan petani setelah panen dilakukan dengan besaran biaya sama dengan yang dipinjamkan oleh pemilik kios saprodi.

Sistem pinjaman dengan pedagang pengumpul juga dilakukan oleh petani Brokoli di daerah penelitian. Hasil penelitian menunjukan bahwa sebesar 4,44\% petani menggunakan sistem pembiayaan seperti ini. Berbeda dengan kedua jenis pembiayaan sebelumnya, pada sistem pembiayaan ini petani memiliki perjanjian kepada pemilik modal seperti harus menjual komoditi yang dihasilkan kepada pemilik modal dengan harga yang ditetapkan. Sistem pembiayaan seperti ini jarang dilakukan petani karena petani tidak dapat leluasa menjual komoditi kepada pihak pemeberi harga tinggi. Berikut merupakan tabel 2 yang menjelaskan alokasi penggunaan modal usahatani Brokoli di Desa Sumber Urip.

Tabel 2. Alokasi Penggunaan Modal Usahatani Brokoli di Desa Sumber Urip

\begin{tabular}{llrcc}
\hline No & \multicolumn{1}{c}{$\begin{array}{c}\text { Alokasi } \\
\text { Penggunaan }\end{array}$} & $\begin{array}{c}\text { Biaya } \\
(\mathrm{Rp} / \mathrm{Ut} / \mathrm{MT})\end{array}$ & $\begin{array}{c}\text { Biaya } \\
(\mathrm{Rp} / \mathrm{Ha})\end{array}$ & $\begin{array}{c}\text { Persentase } \\
(\%)\end{array}$ \\
\hline 1 & Benih & 462.556 & $2.890 .975,0$ & 14,61 \\
2 & Pupuk & 1.215 .748 & $7.598 .425,0$ & 38,40 \\
3 & Pestisida & 610.322 & $3.814 .512,5$ & 19,28 \\
5 & Tenaga Kerja Luar & 681.000 & $4.256 .250,0$ & 21,51 \\
& Keluarga & 196.378 & $1.227 .362,5$ & 6,20 \\
6 & Lahan & $\mathbf{3 . 1 6 6 . 0 0 4}$ & $\mathbf{1 9 . 7 8 7 . 5 2 5 , 0}$ & $\mathbf{1 0 0 , 0 0}$ \\
\hline
\end{tabular}

Sumber: Data Primer Diolah, 2016 
Rata-rata modal yang dikeluarkan petani dalam satu kali musim tanam usahatani Brokoli yaitu sebesar Rp 3.166.004/Ut/MT. Modal tersebut diperuntuhkan untuk membeli sarana produksi seperti benih, pupuk, pestisida, peralatan, sewa lahan dan upah tenaga kerja. Dalam kegiatan usahatani Brokoli dengan rata-rata luas lahan 0,16 Ha biaya input produksi terbesar yang dikeluarkan petani yaitu biaya Pupuk yakni sebesar Rp 1.215.748/Ut/MT atau 38,40\% dari total alokasi penggunaan modal. Pupuk merupakan input produksi yang sangat erat kaitannya dengan kualitas tanah, dengan semakin tersedianya kandungan yang dibutuhkan tanah maka akan mendorong jumlah produksi yang dihasilkan dengan memaksimalkan penggunaan pupuk diharapkan kualitas dan kuantitas Brokoli akan meningkat. Sedangkan biaya penggunaan input terendah yaitu biaya lahan yakni sebesar Rp 196,378/Ut/MT atau Rp 1.227.362,5/Ha.

\section{Biaya Produksi Usahatani Brokoli}

Biaya produksi usahatani merupakan keseluruhan biaya yang dikeluarkan petani dalam satu kali kegiatan usahatani. Biaya produksi dibagi menjadi dua kelompok yaitu biaya variabel dan biaya tetap. Biaya variabel terdiri biaya pupuk, pestisida, benih, tenaga kerja luar dan dalam keluarga sedangkan biaya tetap terdiri dari biaya penyusutan peralatan dan biaya sewa lahan. Secara lebih rinci dapat dilihat pada tabel 3.

Tabel 3. Rata-rata Total Biaya Pada Usahatani Brokoli di Desa Sumber Urip

\begin{tabular}{llcc}
\hline No & \multicolumn{1}{c}{ Uraian } & $\begin{array}{c}\text { Rata-Rata Biaya } \\
(\mathrm{Rp} / \mathrm{Ut} / \mathrm{MT})\end{array}$ & $\begin{array}{c}\text { Rata-Rata Biaya } \\
(\mathrm{Rp} / \mathrm{Ha})\end{array}$ \\
\hline $\mathbf{1}$ & Biaya Variabel & 462.556 & \\
& Benih & 1.215 .748 & $2.890 .975,0$ \\
& Pupuk & 610.322 & $7.598 .425,0$ \\
& Pestisida & 1.845 .889 & $3.814 .512,5$ \\
& TK Dalam Keluarga & 681.000 & $11.536 .806,2$ \\
& TK Luar Keluarga & & $4.256 .250,0$ \\
$\mathbf{2}$ & Biaya Tetap & 184.583 & \\
& Penyusutan Alat & 196.378 & $1.153 .643,7$ \\
& Sewa Lahan & $\mathbf{5 . 1 9 6 . 4 7 6}$ & $\mathbf{3 2 . 4 7 7 . 9 7 4 , 9}$ \\
\hline Jumlah & & \\
\hline
\end{tabular}

Sumber: Data Primer Diolah, 2016

Rata-rata total biaya produksi yang dikeluarkan petani Brokoli di desa Sumber Urip adalah $\mathrm{Rp}$ 5.196.476/Ut/MT atau $\mathrm{Rp} 32.477 .974,9 / \mathrm{Ha}$. Sumbangsi biaya terbesar terdapat pada biaya tenaga kerja dalam keluarga yaitu sebesar Rp 1.845.889/Ut/MT. Besarnya biaya tenaga kerja dalam keluarga ini dikarenakan mayoritas kegiatan usahatani Brokoli tidak begitu rumit sehingga pengerjaan sebagian besar kegiatan usahatani dapat dikerjakan oleh tenaga kerja dalam keluarga dan lahan yang digunakan juga mayoritas masih kecil sehingga petani tidak begitu membutuhkan tenaga kerja luar 
keluarga dalam melaksanakan usahatani Brokoli, hanya kegiatan-kegiatan seperti pengolahan tanah, pembuatan bedengan, dan pemanenan yang biasanya menggunakan tenaga kerja luar keluarga. Biaya penyusutan alat menjadi biaya terendah pada usahatani Brokoli yaitu sebesar Rp 184.583/Ut/MT. Kecilnya biaya penyusutan alat tersebut dikarenakan jumlah alat yang digunakan dalam usahatani Brokoli sedikit antara lain cangkul, sabit, pisau panen, dan alat semprot dan harga dari setiap alat relatif murah.

Bila dibandingkan dengan penelitian Wijaya (2012) dengan rata-rata luas lahan 0,32 Ha total biaya yang dikeluarkan untuk usahatani Brokoli yaitu sebesar Rp 5.318.565,09/Ut/MT, bila dikonversi pada luas lahan 0,16 yaitu sebesar Rp 2.659.282,54/Ut/MT. Sedangkan di Desa Sumber Urip rata-rata luas lahan yang digunakan 0,16 Ha dan total biaya yang dikeluarkan $\mathrm{Rp}$ 5.196.476/Ut/MT. Perbedaan yang cukup signifikan tersebut dipengaruhi oleh jumlah penggunaan input produksi. Dapat disimpulkan bahwa dari segi penggunaan biaya usahatani Brokoli di Desa Muara Perikan lebih efisien dibandingkan dengan di Desa Sumber Urip.

\section{Produksi Usahatani Brokoli}

Produksi usahatani merupakan jumlah Brokoli yang dihasilkan dari kegiatan usahatani baik yang dijual maupun yang dikonsumsi oleh keluarga petani. Dari hasil penelitian yang dilakukan rata-rata hasil produksi Brokoli di Desa Sumber Urip yaitu sebanyak $1.801 \mathrm{Kg} / \mathrm{Ut} / \mathrm{MT}$ dengan rata-rata luas lahan yang digunakan 0,16 Ha. Bila dibandingkan dengan penelitian Wijaya (2012) produksi Brokoli di Desa Muara Perikan Kota Pagaralam dengan ratarata luas lahan 0,16 yaitu $1.560 \mathrm{Kg} / \mathrm{Ut} / \mathrm{MT}$ hal ini menunjukan bahwa usahatani Brokoli di Desa Sumber Urip lebih tinggi produksinya bila dibandingkan dengan usahatani Brokoli di Desa Muara Perikan. Sehingga dapat menjadi potensi yang baik bagi petani dalam mengembangkan usahatani Brokoli karena bila dibandingkan produksinya dengan Usahatani Brokoli di Desa Sumber Urip masih lebih dominan tinggi dibanding di Desa Muara Perikan kota Pagaralam.

\section{Analisa Pendapatan Usahatani Brokoli}

Pendapatan yang diperoleh petani Brokoli sangat dipengaruhi dengan biaya penggunaan saprodi, jumlah produksi dan harga jual komoditi Brokoli. Secara rinci Total biaya dan pendapatan usahatani Brokoli di Desa Sumber Urip dapat dilihat pada tabel 4.

Tabel 4. Rata-rata Penerimaan dan Pendapatan Usahatani Brokoli

\begin{tabular}{llrc}
\hline No & \multicolumn{1}{c}{ Uraian } & $\mathrm{Rp} / \mathrm{Ut} / \mathrm{MT}$ & $\mathrm{Rp} / \mathrm{Ha}$ \\
\hline 1 & Penerimaan & 10.806 .667 & $67.541 .668,8$ \\
2 & Total Biaya & 5.196 .476 & $32.477 .975,0$ \\
3 & Pendapatan & 5.610 .191 & $35.063 .693,8$ \\
\hline
\end{tabular}

Sumber: Data Primer Diolah, 2016

246 | Bembi Akbar S., Sriyoto, dan Ellys Y., Analisis Usahatani Brokoli... 
Penerimaan merupakan sejumlah uang yang diperoleh petani dari hasil penjualan Brokoli yang belum dikurangi dengan biaya-biaya selama kegiatan usahatani. Untuk mengetahui penerimaan usahatani Brokoli maka produksi yang dihasilkan dikali dengan harga jual Brokoli pada waktu bersangkutan, harga jual rata-rata di tingkat petani adalah $\mathrm{Rp} 6.000 / \mathrm{kg}$. Rata-rata penerimaan petani Brokoli di Desa Sumber Urip yaitu Rp 10.806.667/Ut/MT atau $\mathrm{Rp} 67.541 .668,8 / \mathrm{Ha}$.

Pendapatan merupakan penerimaan dikurangi dengan total biaya produksi yang dikeluarkan petani selama kegiatan usahatani. Pendapatan rata-rata petani Brokoli di Desa Sumber Urip yaitu sebesar Rp 5.610.191/Ut/MT atau Rp 35.063.693,8/Ha. Jumlah pendapatan tersebut lebih tinggi bila dibandingkan dengan pendapatan petani di Desa Muara Perikan Kota Pagaralam, hasil penelitian Wijaya (2012) di Desa Muara Perikan Kota Pagaralam pendapatan rata-rata petani Brokoli sebesar Rp 5.513.106/Ut/MT atau $\mathrm{Rp} 34.456 .912,5 / \mathrm{Ha}$ dengan luas lahan 0,16. Perbedaan pendapatan di kedua daerah tersebut dipengaruhi oleh total produksi Brokoli yang dihasilkan, petani di Desa Sumber Urip memiliki produksi yang lebih tinggi dibandingkan dengan di Desa Muara Perikan, sehingga hal ini mempengaruhi Pendapatan yang diperoleh petani.

\section{Analisa Pemasaran}

\section{Saluran dan Distribusi Pemasaran Brokoli}

Produksi Brokoli yang dihasilkan petani bisanya langsung dijual kepada Pedagang Pengumpul Desa atau Pedagang Pengumpul Kecamatan. Hasil penelitian menunjukan bahwa Brokoli di Desa Sumber Urip sebagian besar dijual ke luar Propinsi Bengkulu diantaranya dijual ke Kota Palembang, dan Bangka Belitung. Penelusuran pemasaran Brokoli pada penelitian ini mulai dari petani hingga pedagang pengecer di kota Palembang sedangkan pemasaran di Bangka Belitung tidak dianalisa karena peneliti terbatas waktu dan biaya. Dari hasil penelitian yang dilakukan di Desa Sumber Urip terdapat 3 pola saluran pemasaran Brokoli antara lain:

Pola 1:

Petani $\rightarrow$ Pedagang Pengumpul Desa $\rightarrow$ Pedagang Pengumpul Kecamatan $\rightarrow$ Pedagang Pengumpul Kota Palembang $\rightarrow$ Pedagang Pengecer $\rightarrow$ Konsumen

Pola 2:

Petani $\rightarrow$ Pedagang Pengumpul Desa $\rightarrow$ Pedagang Pengumpul Kecamatan $\rightarrow$ Pedagang Pengumpul Kota Lain $\rightarrow$ Pedagang Pengecer $\rightarrow$ Konsumen

Pola 3:

Petani $\rightarrow$ Pedagang Pengumpul Kecamatan $\rightarrow$ Pedagang Pengecer $\rightarrow$ Konsumen 
Karena peneliti terbatas waktu dan biaya maka dalam penelitian ini peneliti hanya menganalisa saluran pemasaran pola 1. Berikut merupakan distribusi pemasaran Brokoli dai hasil penelitian yang dilakukan.

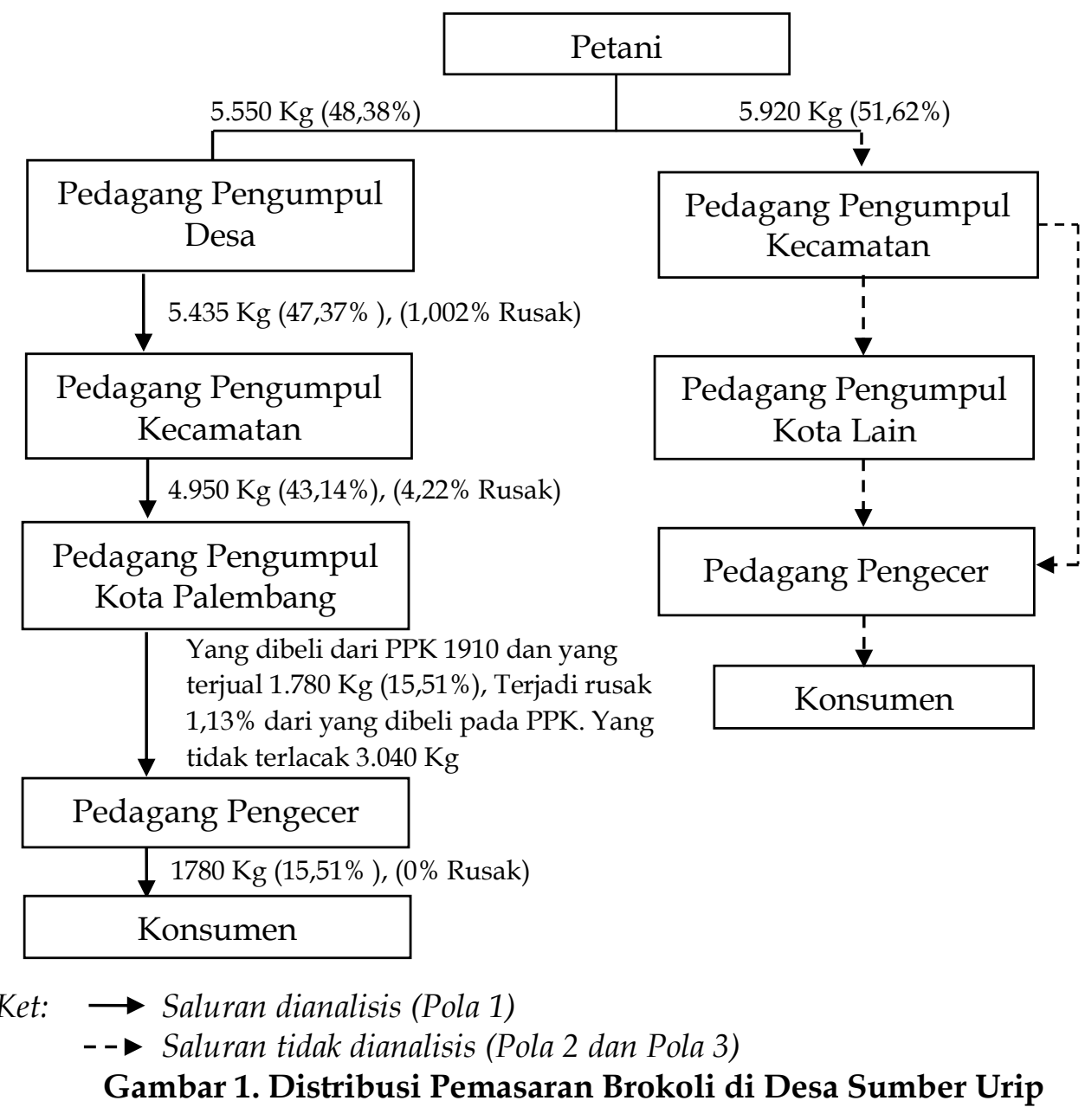

Dari hasil penelitian yang dilakukan total penjualan Brokoli yang dilakukan petani sebesar $5.550 \mathrm{Kg}$ atau $48,38 \%$ dari jumlah yang dihasilkan petani. Selanjutnya Pedagang Pengumpul Desa menjual Brokoli ke Pedagang Pengumpul kecamatan sebanyak $5.435 \mathrm{Kg}$ atau sebesar $47,37 \%$ dari jumlah yang dibeli dari petani, terjadi penyusutan sebesar $1,002 \%$, penyusutan ini terjadi dikarenakan Pedagang Pengumpul Desa melakukan pembersihan daun dan pemotongan batang Brokoli yang terlalu panjang.

Hasil penelitian menunjukan jumlah Brokoli yang diterima Pedagang Pengumpul Kecamatan sebanyak 5.435 Kg. Pedagang pengumpul Kecamatan merupakan lembaga yang paling banyak melakukan perlakuan terhadap komoditi Brokoli sebelum dijual seperti pembersihan bagian yang rusak, melakukan penyortiran terhadap Brokoli yang tidak layak pasar dan pengemasan, hal tersebut menyebabkan timbulnya penyusutan Brokoli

248 | Bembi Akbar S., Sriyoto, dan Ellys Y., Analisis Usahatani Brokoli... 
sebesar 4,22\% dari total pembelian. Total penjualan Brokoli Pedagang Pengumpul Kecamatan yaitu $4.950 \mathrm{Kg}$ atau sebesar 43,14\% dari total yang dihasilkan petani.

Pada penelitian terjadi rentang waktu ketika penelusuran distribusi Brokoli sehingga Jumlah Brokoli yang ditemukan dilapangan tidak sama dengan yang dipasarkan Pedagang Pengumpul Kecamatan. Dari $4.950 \mathrm{Kg}$ yang tidak terlacak sebanyak $3.040 \mathrm{Kg}$ dan yang terlacak pada Pedagang Pengumpul Kota Palembang sebanyak $1.910 \mathrm{Kg}$ dan yang terjual ke Pedagang Pengecer sebanyak 1.780, terjadi penyusutan komoditi ketika berada pada Pedagang Pengumpul Kota Palembang hal ini dikarenakan Pedagang Pengumpul Kota melakukan fungsi pemasaran yaitu fungsi fisik dengan melakukan penyortiran dan membersihkan bagian Brokoli yang tidak layak jual dan selanjutnya dijual kepada Pedagang Pengecer. Selanjutnya Pedagang Pengecer membeli Brokoli dari Pedagang Pengumpul Kota dengan total pembelian sebesar $1780 \mathrm{Kg}$ dan yang terjual sebesar $1780 \mathrm{Kg}$ dari total pembelian yang dilakukan, artinya seluruh Brokoli yang dibeli dari Pedagang Pengumpul Kota terjual habis di tingkat Pedagang Pengecer.

\section{Marjin pemasaran Brokoli}

Pendekatan analisis yang dapat digunakan untuk melihat efisiensi operasional kegiatan pemasaran dari setiap saluran salah satunya adalah dengan mengetahui marjin pemasaran. Perhitungan marjin dan keuntungan pemasaran dapat dilihat pada tabel 5.

Dari hasil analisis, diperoleh harga Brokoli yang diterima petani sebesar Rp 6.000/kg sedangkan harga jual pada konsumen akhir di tingkat pedagang pengecer sebesar Rp 17.750/ kg, terdapat selisih harga yang tinggi antara harga diterima petani dan harga pada konsumen akhir terhadap komoditi Brokoli, hal ini disebabkan karena panjangnya saluran pemasaran, biaya-biaya yang dikeluarkan setiap lemabaga pemasaran semakin banyak dan keuntungan yang diambil setiap lembaga semakin beragam. Persentase perbedaan harga antar petani dan pedagang pengecer yaitu 33,80\%, persentase perbedaan harga di tingkat petani paling kecil bila dibandingkan lembaga pemasaran lain hal ini dikarenakan setiap lembaga akan melakukan fungsi-fungsi pemasaran yang menyebabkan timbulnya biaya dan akan berpengaruh pada harga jual komoditi Brokoli. Sementara total marjin pada pemasaran Brokoli mulai dari petani sampai dengan pedagang pengecer yaitu Rp 11.750/kg atau 66,19\%. Total marjin merupakan akumulasi dari setiap marjin lembaga pemasaran yang terdiri dari pedagang penegecer pengumpul desa sebesar 5,63\%, pedagang pengumpul kecamatan sebesar $16,90 \%$, pedagang pengumpul kota Palembang sebesar 20,66\% dan pedagang pengecer sebesar 23,00\%. 


\section{Tabel 5. Marjin Pemasaran Brokoli}

\begin{tabular}{|c|c|c|c|}
\hline No & Uraian & Jumlah $(\mathrm{Rp} / \mathrm{Kg})$ & Persentase $(\%)^{*}$ \\
\hline \multirow[t]{2}{*}{1} & Petani & & \\
\hline & a. Harga Jual & 6.000 & 33,80 \\
\hline \multirow[t]{11}{*}{2} & Pedagang Pengumpul Desa & & \\
\hline & a. Harga Beli & 6.000 & 33,80 \\
\hline & b. Biaya Pemasaran & & \\
\hline & - Biaya Tenaga Kerja & 236 & 1,33 \\
\hline & - Biaya Keranjang & 111 & 0,62 \\
\hline & - Biaya Tali Plastik & 47 & 0,26 \\
\hline & - Biaya Penyusutan Timbangan & 26 & 0,15 \\
\hline & - Biaya Penyusutan Kalkulator & 18 & 0,10 \\
\hline & - Keuntungan & 562 & 3,17 \\
\hline & - Marjin Pemasaran & 1.000 & 5,63 \\
\hline & - Harga Jual & 7.000 & 39,44 \\
\hline \multirow[t]{10}{*}{3} & $\begin{array}{l}\text { Pedagang Pengumpul Kecamatan } \\
\text { a. Harga Beli } \\
\text { b. Biaya Pemasaran }\end{array}$ & 7.000 & 39,44 \\
\hline & - Biaya Transportasi & 111 & 0,62 \\
\hline & - Biaya Bongkar Muat & 150 & 0,84 \\
\hline & - Biaya Keranjang & 116 & 0,65 \\
\hline & - Biaya Tali Plastik & 49 & 0,28 \\
\hline & - Biaya Penyusutan Timbangan & 22 & 0,12 \\
\hline & - Biaya Penyusutan Kalkulator & 12 & 0,07 \\
\hline & - Keuntungan & 2.540 & 14,31 \\
\hline & - Marjin Pemasaran & 3.000 & 16,90 \\
\hline & - Harga Jual & 10.000 & 56,34 \\
\hline \multirow[t]{10}{*}{4} & $\begin{array}{l}\text { Pedagang Pengumpul Kota Palembang } \\
\text { a. Harga Beli }\end{array}$ & 10.000 & 56,34 \\
\hline & b. Biaya Pemasaran & & \\
\hline & - Biaya Tenaga Kerja & 713 & 4,02 \\
\hline & - Biaya Sewa Kios & 392 & 2,21 \\
\hline & - Biaya Karung & 160 & 0,90 \\
\hline & - Biaya Penyusutan Timbangan & 21 & 0,12 \\
\hline & - Biaya Penyusutan Kalkulator & 6 & 0,03 \\
\hline & - Keuntungan & 2.375 & 13,38 \\
\hline & - Marjin Pemasaran & 3.667 & 20,66 \\
\hline & - Harga Jual & 13.667 & 76,99 \\
\hline \multirow[t]{15}{*}{5} & Pedagang Pengecer & & \\
\hline & a. Harga Beli & 13.667 & 76,99 \\
\hline & b. Biaya Pemasaran & & \\
\hline & - Biaya Tenaga Kerja & 45 & 0,25 \\
\hline & - Biaya Sewa Lapak & 94 & 0,53 \\
\hline & - Biaya Retribusi & 12 & 0,07 \\
\hline & - Biaya Kantong Plastik & 25 & 0,14 \\
\hline & - Biaya Penyusutan Timbangan & 13 & 0,07 \\
\hline & - Biaya Penyusutan Kalkulator & 13 & 0,07 \\
\hline & - Keuntungan & 3.881 & 21,86 \\
\hline & - Marjin Pemasaran & 4.083 & 23,00 \\
\hline & - Harga Jual & 17.750 & 100 \\
\hline & Total Biaya Pemasaran & 2.392 & 13,47 \\
\hline & Total Keuntungan & 9.358 & 52,72 \\
\hline & Total Marjin Pemasaran & 11.750 & 66,19 \\
\hline
\end{tabular}

Sumber: Data Primer Diolah, 2016

Keterangan: *) Persentase terhadap harga jual pedagang pengecer (Rp 17.750/Kg) 
Keuntungan setiap lembaga pemasaran berbeda-beda hal ini dikarenakan setiap lembaga pemasaran menjalankan peran dan fungsi pemasaran yang berbeda-beda. Keuntungan pemasaran merupakan imbal jasa atas jasa yang dilakukan selama proses melakukan proses pemasaran. Total keuntungan pemasaran Brokoli mulai dari petani sampai dengan pedagang pengecer yaitu Rp 9.358/ kg atau sebesar 52,72\% terhadap harga jual Brokoli pada konsumen akhir. Hasil penelitian menunjukan lembaga pemasaran yang mengambil keuntungan tertinggi yaitu pedagang pengecer dengan nominal $\mathrm{Rp} 3.881 / \mathrm{kg}$, hal ini disebabkan biaya-biaya pemasaran yang dikeluarkan pedagang pengecer dan besarnya resiko kerusakan pada Brokoli sehingga tidak dapat dijual lagi serta waktu pedagang penegecer dalam memasarkan Brokoli cukup lama.

\section{Efisiensi Pemasaran Brokoli}

Efisiensi pemasaran dilihat dengan menghitung rasio keuntungan dan biaya. Rasio keuntungan dan Biaya akan menggambarkan apakah pemasaran dikatakan efisien atau tidak dengan kriteria nilai rasio keuntungan dan biaya $>1$ pemasaran efisien dan $<1$ pemasaran tidak efisien. Secara rinci nilai efisiensi pemasaran Brokoli di Desa Sumber Urip dapat dilihat pada tabel 6 .

\section{Tabel 6. Efisiensi Pemasaran Brokoli}

\begin{tabular}{llrrrrl}
\hline No & $\begin{array}{c}\text { Jenis } \\
\text { Pembaga }\end{array}$ & $\begin{array}{r}\text { Total Biaya } \\
\text { Pemasaran } \\
(\mathrm{Rp} / \mathrm{Kg})\end{array}$ & $\begin{array}{c}\text { Marjin } \\
\text { pemasaran } \\
(\mathrm{Rp} / \mathrm{Kg})\end{array}$ & $\begin{array}{c}\text { Keuntungan } \\
(\mathrm{Rp} / \mathrm{Kg})\end{array}$ & $\begin{array}{c}\text { Rasio } \\
\text { Keuntungan } \\
\text { dan Biaya }\end{array}$ & Kriteria \\
\hline 1 & PPD & 438 & 1.000 & $\mathbf{5 6 2}$ & 1,28 & Efisien \\
2 & PPK & 460 & 3.000 & 2.540 & 5,52 & Efisien \\
3 & PPKP & 1.292 & 3.667 & 2.375 & 1,83 & Efisien \\
4 & PP & 202 & 4.083 & 3.881 & 19,21 & Efisien \\
\hline & Jumlah & $\mathbf{2 . 3 9 2}$ & $\mathbf{1 1 . 7 5 0}$ & $\mathbf{9 . 3 5 8}$ & $\mathbf{2 7 , 8 4}$ & \\
\hline
\end{tabular}

Sumber: Data Primer Diolah, 2016

Hasil penelitian menunjukan bahwa pemasaran Brokoli di Desa Sumber Urip sudah efisien hal ini terlihat dari nilai rasio keuntungan dan biaya setiap lembaga sudah lebih dari satu. Nilai rasio keuntungan dan biaya paling tinggi yaitu pada Pedagang Pengecer sebesar 5,48 hal ini menunjukan bahwa efisiensi pemasaran paling tinggi berada pada PP. PP merupakan lembaga pemasaran yang paling tinggi mengambil keuntungan hal ini dikarenakan resiko kerusakan pada Brokoli sehingga tidak dapat dijual lagi serta waktu pedagang pengecer dalam memasarkan Brokoli cukup lama.

Menurut Ningsih (2013) keuntungan pemasaran dipengaruhi oleh besarnya jasa yang dicurahkan setiap lembaga dan tingkat resiko yang harus ditanggung oleh setiap pedagang, semakin besar resiko yang dihadapi maka pedagang akan cenderung memperbesar keuntungan yang diharapkan. Hal ini digunakan untuk menutup kerugian jika resiko tersebut benar-benar terjadi. 


\section{SIMPULAN DAN SARAN}

\section{Simpulan}

Berdasarkan hasil penelitian dan analisis yang dilakukan maka didapatkan beberapa kesimpulan, antara lain:

1. Pembiayaan Usahatani Brokoli di Desa Sumber Urip mayoritas menggunakan modal sendiri yang diperoleh dari kegiatan usahatani sebelumnya. Dari 45 responden, 40 diantaranya menggunakan modal sendiri dalam kegiatan usahatani Brokoli dan 5 responden melakukan pinjaman kepada pihak ketiga dalam melakukan kegiatan usahatani Brokoli

2. Rata-rata total biaya yang dikeluarkan petani Brokoli di Desa Sumber Urip yaitu Rp 5.196.476/Ut/MT atau Rp 32.477.975/Ha, rata-rata penerimaan yang diperoleh petani Brokoli sebesar Rp 10.806.667/Ut/MT atau Rp 67.541.668,8 . Sehingga rata-rata pendapatan yang diperoleh petani Brokoli di Desa Sumber Urip yaitu Rp 5.610.191/Ut/MT atau Rp 35.063.693,8/Ha

3. Pola saluran pemasaran Brokoli di Desa Sumber Urip yang paling banyak terjadi yaitu Petani, Pedagang Pengumpul Desa, Pedagang Pengumpul Kecamatan, Pedagang Pengumpul Kota, Pedagang Pengecer.

4. Hasil analisa distribusi pemasaran Brokoli di Desa Sumber Urip petani menjual 100\% hasil produksi Brokoli, dimana masing-masing tersebar ke Pedagang Pengumpul Desa Sebesar 48,38\% dan 51,62\% kepada Pedagang Pengumpul Kecamatan. PPD menjual sebesar 47,37\%, PPK 43,14\%, PPKP 15,51\% dan PP 15,51\% dari total produksi petani.

5. Total marjin pada pemasaran Brokoli yaitu sebesar Rp 11.750/Kg. Lembaga yang memiliki proporsi marjin terbesar yaitu pedagang pengecer sebesar Rp 4.083/Kg atau 23,00\% dari harga jual akhir Brokoli. Pemasaran Brokoli di Desa Sumber Urip sudah efisien hal terlihat dari nilai rasio keuntungan dan biaya di tiap pedagang. PPD sebesar 1,28; PPK sebesar 5,52; PPKP sebesar 1,83 dan PP 19,21\%.

\section{Saran}

Dari hasil penelitian yang dilakukan maka diperoleh saran untuk berbagai pihak yaitu:

1. Bagi Kios Saprodi

Petani memiliki kendala dalam mendapatkan benih Brokoli. Sebaiknya pihak kios saprodi yang berada di kecamatan Selupu Rejang dan sekitarnya harus persediaan stok benih Brokoli agar kegiatan usahatani Brokoli di Desa Sumber Urip dapat dilaksanakan secara berkelanjutan.

2. Bagi Instansi Pemerintah

Kurangnya pengetahuan petani akan cara pembenihan membuat petani sangat bergantung pada kios saprodi yang menjual benih Brokoli. Saran kepada instansi pemerintah kabupaten Rejang Lebong agar memberikan pelatihan tatacara melakukan pembenihan sehingga petani dapat melakukan kegiatan pembenihan sendiri dan tidak bergantung pada kios saprodi. 
3. Bagi petani

Petani sebaiknya lebih sering berusahatani Brokoli hal ini dikarenakan tanaman Brokoli memiliki potensi yang cukup baik di pasaran dan produksi usahatani Brokoli di Desa Sumber Urip lebih tinggi bila dibandingkan dengan daerah penghasil sayuran seperti di Desa Muara Perikan Kota Pagaralam.

4. Bagi Lembaga Pemasaran

Tingginya kerusakan produk membuat produksi Brokoli yang dihasilkan petani masih banyak yang terbuang percuma sehingga sebaiknya lembaga pemasaran lebih mengedepankan aspek teknis dalam melaksanakan fungsifungsi pemasaran seperti pemberian fasilitas terhadap Brokoli yang akan dipasarkan ke daerah yang memiliki jarak tempuh jauh sehingga Brokoli yang dipasarakan tidak memiliki kerusakan yang tinggi.

\section{DAFTAR PUSTAKA}

BPS. 2013. Luas Panen Tanaman Sayuran Menurut Kabupaten/Kota di Provinsi Bengkulu. Badan Pusat Statistik. Bengkulu.

Limbong, W.H., dan P. Sitorus. 1987. Pengantar Tataniaga Pertanian. Bahan Kuliah Departemen Sosial Ekonomi Pertanian. IPB. Bogor.

Ningsih, K. 2013. Analisis Saluran dan Marjin Pemasaran Petani Jambu Air Camplong (Syzygium aqueum). http://jurnal.yudharta.ac.id/wpcontent/uploads/2013/04/3-kustiawati-NingsihANALISIS-SALURANDAN-MARJIN-PEMASARAN.pdf. Diakses 24 Juni 2016.

Soekartawi. 1995. Analisis Usahatani. UI-Press, Jakarta.

Soekartawai. 2003. Agribisnis, Teori dan Aplikasinya. PT Raja Grafindo Persada. Jakarta.

Susanti, T. Rita Ratini, Mariyah. 2014. Analisis Pendapatan dan Pemasaran Usahatani Pepaya Mini (Carica papaya L) di Kelurahan Taritip Kecamatan Balikpapan Timur Kota Balikpapan. Jurnal Agrifor: Vol 13 (1).

Wijaya, D., Satria Putra Utama., Indra Cahyadinata. 2012. Analisis Pendapatan dan Pemasaran Usahatani Brokoli di Desa Muara Perikan Kecamatan Pagaralam. Jurnal Agrisep: Vol 11 (2): 176. 
